\title{
Orantılı Hazard Varsayımının Maden Kazalarında İstatistiksel Olarak İncelenmesi
}

\author{
The Statistical Investigation of the Proportional Hazard \\ Assumption in Mine Accidents
}

\section{Özgül VUPA ÇILENGIROĞLU}

\begin{abstract}
ÖZET
Türkiye'de son yıllarda meydana gelen iş kazaları, iş sağlığı ve güvenliğinin önemini yeniden gündeme taşımaktadır. Özellikle madencilik sektörü birçok iş kazasının yaşandığı tehlikeli iş kolları arasında yer almaktadır. Bu çalışmada 2009-2011 yılları arasında Türkiye Maden Mühendisleri Odasından yeraltı kömür maden ocağına ait kaza bilgileri alınmıştır. Ölümlü kaza gerçekleşinceye kadar geçen sürenin analizi için çeşitli faktörlere göre Kaplan-Meier yöntemiyle medyan sağkalım süreleri elde edilmiştir. Cox regresyon modelinde işçi sayısı, havalandırma, gaz ölçüm koşulu ve kömür tozu miktarı değişkenleri istatistiksel olarak anlamlı bulunmuştur. Ancak orantılı hazard varsayımının kontrolü ile tabakalı Cox regresyon modeli kullanılmış ve işçi sayısının az olduğu madenler için uygun havalandırma ve gaz ölçümü yapıldığı taktirde ölümlü kazaların daha uzun sürede gerçekleştiği tespit edilmiştir.
\end{abstract}

Anahtar Kelimeler: Maden Kazaları, Kaplan-Meier, Cox Regresyon, Orantılı Hazard Varsayımı

\section{ABSTRACT}

In recent years, the occupational accidents in our country again bring to the agenda the importance of occupational health and safety. In particular, the mining sector is one of the most dangerous business lines with many occupational accidents. In this study, the underground coal mine accident data was taken from Turkey Mining Engineers Chamber between the years 2009-2011. Median survival times were obtained by Kaplan-Meier method according to various factors for the analysis of the time until death. In the Cox regression model, the number of workers, the ventilation, the gas measurement condition and the amount of coal dust were found to be statistically significant. However the stratified Cox regression model was used with the control of proportional hazard assumption. It was determined that fatal accidents occurred in a longer period if appropriate ventilation and gas measurement were made for the mines where the number of workers was small.

Keywords: Mine Accidents, Kaplan-Meier, Cox Regression, Proportional Hazard Assumption

Dr. Öğr. Üyesi Özgül VUPA çiLENGiROĞLU - Dokuz Eylül Üniversitesi, Fen Fakültesi, İstatistik Bölümü, İzmir, Türkiye Assist. Prof. Dr. Özgül VUPA ÇiLENGiROĞLU — Dokuz Eylül University, Faculty of Science, Department of Statistics, izmir, Turkey ORCID ID: 0000-0003-0181-8376

ozgul.vupa@deu.edu.tr 


\section{GİRİ̧̧}

Tarih boyunca toplumsal hayatın vazgeçilmez bir unsuru olan madencilik sektörü, bir ülkenin teknoloji ve refah düzeyinin gelişmesinde etkilidir. Madencilik sektörü, imalat, enerji ve sanayi sektörüne yapmış olduğu katkılardan ve de istihdam yaratma gücünün yüksek olmasından dolayı sanayileşme faktörü yüksek olan bir sektördür. Sanayileşmenin başlangıcında hammadde ihtiyacı bulunduğundan ve dünyada hammaddeye olan ihtiyacın günden güne artmasından dolayı madencilikteki üretim miktarları da etkilenmektedir [1]. Bu üretim miktarlarının karşılanabilmesi için maden kaynakların iyi bir şekilde belirlenmesi, işlenmesi ve tüketilmesi önemlidir. Madencilikteki maden kaynakları olarak petrol, doğalgaz, kömür, linyit vb... birçok enerji kaynağı kullanılmaktadır. Türkiye enerji kaynağı olarak büyük ölçüde kömür ve linyit gibi yeraltı maden kaynaklarını kullanmasına rağmen dünya rezervinin ancak \%3.2'sine sahiptir. "Dünya Enerji Konseyi" tarafından yayınlanan raporda ise dünya linyit/kömür rezervlerinin en büyük kısmı ABD, Rusya Federasyonu ve Çin'de olduğu belirtilmektedir [2].

Madencilik sektöründe ABD, Rusya Federasyonu ve Çin gibi etkili ülkelerin ekonomik gücünün oluşmasında, maden rezervlerinin büyüklüğü ve bu madenlerin en iyi şekilde işlenmesi etkilidir. Özellikle imalat ve enerji sektöründe önemli olan maden üretiminin artması, iş güvenliği sorunlarını da beraberinde getirmektedir [1]. İş güvenliği denilince ilk olarak iş kazası düşünülmektedir. İş kazası, önceden planlanmamış, çoğu zaman ölümlere, yaralanmalara, makine ve teçhizatın zarara uğramasına veya üretimin bir süre durmasına yol açan, gerekli tedbirler alındığında çoğunlukla önlenebilen olaylar şeklinde tanımlanabilir. İş güvenliği ise, iş ortamında sağlıklı ve güvenli çalışma koşullarını oluşturarak; iş kazaları ve meslek hastalıklarını en alt düzeye indirmek böylece maddi ve manevi kayıpları önleyerek verimliliği artırmak şeklinde ifade edilebilir [3]. İş sağllğ 1 ve güvenliğinde önleme ve korunma birincil hedeftir. Bu yüzden ölümlere neden olan risklerin belirlenmesi ve düzeltilmesi iş güvenliği açısından oldukça önemlidir.

İş güvenliği kapsamında madencilik sektörü, iş kazalarının meydana geldiği en tehlikeli çalışma kollarından birisidir [4,5]. Türkiye’de 1997 yılından günümüze kadar olan iş kazalarından kaynaklı ölümlerin oranında zaman zaman azalış görülse de genel olarak bir artış söz konusudur. İş kazalarının sektörlere göre dağılımında madencilik ve metal sanayi ilk sıralarda bulunmaktadır [6]. Dünyada çalışanların sadece \%1'i madenlerde bulunurken, meydana gelen ciddi kazaların \%8'i madencilik sektöründe olmaktadır [7]. Türkiye'de ve dünyada maden ocaklarında ölümün ve yaralanmanın büyük oranda kömür ocaklarında meydana geldiği görülmektedir [8].

Yeraltı ve yerüstü olarak ayrılan madencilik sektöründe iş güvenliği açısından yeraltı madenciliği daha tehlikeli bulunmaktadır [4]. Yeraltı madenciliğinde iş sağlı̆̆ı ve güvenliği açısından ele alınan konular: maden gazları, grizu patlamaları, kömür tozu patlamaları, havalandırma, termal konfor, yangın, tozun neden olduğu hastalıklar, gürültü, titreşim, aydınlatma, tahkimat ve maden göçükleri, patlayıcı madde kullanımı, elektrik, su baskını, mekanizasyon ve makine kullanımı, malzeme ve insan nakliyesi olarak sıralanabilir $[4,9,10,11,12]$. Gerek meslek hastalığına gerekse iş kazalarına neden olabilecek bu tehlikeleri zamanında belirlemek ve gerekli önlemleri almak güvenli bir maden iş hayatı için önemlidir. Bu sebeple belirtilen tehlikelerin meydana geliş nedenlerinin iyi belirlenmesi ve analiz edilmesi gerekmektedir. Bütün faaliyet kollarında olduğu gibi yeraltı madenciliğinde de tehlikenin ve risklerin önceden değerlendirilerek gerekli önlemlerin alınması, çalışan sağlığı, işverenin yükümlülükleri, firma ve ülke ekonomisi için 
önemlidir $[4,13]$.

Türkiye'de son yıllarda meydana gelen maden kazalarının sayısının giderek artması nedeniyle, madencilik sektöründe iş sağlığı ve güvenliği ile ilgili zayıf noktalar tartışılmaya başlanmıştır. Madencilik sektöründe 2012 yılı öncesi iş sağlığı ve iş güvenliği ile ilgili ciddi boşluklar bulunması yüzünden 2012 yılında yürürlüğe giren 6331 sayılı "İş Sağlığı ve Güvenliği Kanunu” ile önemli düzenlemeler yapılmıştır [8]. Bu düzenlemeler 2014 ve 2015 yıllarında daha da geliştirilmiştir. 2017 yılında bu kanuna iş güvenliği uzmanı ve işyeri hekimi görevlendirilmesi ile ilgili hükümler getirilmiştir. Ancak bugüne kadar olan bu yeni düzenlemelerin, son yıllarda yaşanan kayıplarla, uygulanma ve izlenme yönünden zayıf kaldığını göstermektedir. Bu bakımdan bu maden kazalarına ilişkin gerekli önlemlerin alınması ve izlenmesi maden işletmelerinin birincil görevidir. Maden kazaları genel olarak altyapı, teknoloji, yönetim, eğitim ve bilgilendirme ile önlenebilir olması esasına dayanır. Maden kazalarına ilişkin başarılı risk değerlendirme, kazalara neden olan risk faktörlerinin doğru şekilde belirlenmesi, çözümlenmesi ve yorumlanmasını gerektirmektedir. Bu amaçla son yıllarda yapılan istatistiksel değerlendirmeler önem kazanmaktadır.

Bu çalışmanın amacı, yeraltı kömür maden ocaklarında ölümlü kaza gerçekleşinceye kadar geçen sürenin çeşitli risk faktörlerle Kaplan-Meier yöntemi ile hesaplanabilmesi, Cox regresyon analizi ile model kurulması ve varsayımlara bağlı olarak kurulan modelin yorumlanmasıdır.

\section{A. Türkiye ve Dünyada Maden Kazalarının Durumu}

Türkiye'de 2001-2008 yılları arasında meydana gelen yeraltı iş kazalarının \%27.58 ve \%27.11 gibi büyük bir oranı, elle taşıma ve göçük sırasında gerçekleşmiştir [14]. $\mathrm{Bu}$ yıllar arasındaki yeraltı kazalarında kaza nedeni ve iş grupları arasındaki fark ise ANOVA ile bulunmuştur [14].
Aynı şekilde yerüstü kazalarının \%30.99'unun çok büyük bir farkla iş makinesinden kaynaklandığı ve yerüstü kazalarında da kaza nedeni ve iş grupları arasında anlamlı farkın ANOVA ile bulunduğu tespit edilmiştir [14]. 1996-2009 yılları arasında Türkiye Kömür İşletmeleri’ne (TKİ) ait açık işletmelerde meydana gelmiş iş makineleri ile ilgili kazalar loglinear analiz ile incelenmiş, riskli faktörler ve bunlara bağlı etkileşimler belirlenmiştir [15]. ELİ'deki açık işletmelerde meydana gelen iş kazaları, ESAW (Avrupa İş Kazası İstatistikleri) kriterlerine bağlı olarak ikili lojistik regresyon analizi kullanılarak incelenmiş ve çalışma sonunda en riski yerler ve kaza nedenleri bulunmuştur. Ayrıca gün kaybı olasılığını \%88.4 oranında doğru tahminleyen lojistik regresyon modeli elde edilmiştir [16]. TKİne bağlı açık işletmelerde 2006-2011 yılları arasında gün kayıplı kazalar loglinear analizi ile incelenmiş, kazaları etkileyebilecek etkenler ve etkileşimler belirlenerek kazaların azaltılması konusunda tavsiyeler verilmiştir [5]. 1990-2014 yılları arasında dünya genelinde madenlerde meydana gelen 26 adet büyük felaket incelendiğinde 21. yüzyllın en büyük maden kazasının Türkiye'deki 2014 yılında gerçekleşen Soma kömür madeni faciası olduğu belirtilmiştir [8]. Son yıllarda Türkiye'de meydana gelen ölümcül maden kazalarının giderek artmasıyla, madencilik sektöründe iş sağlığı ve güvenliği ile ilgili sistemdeki zayıf noktalar tartışılmaya başlanmıştır [8].

Dünyanın en büyük kömür üreticileri olan Çin, ABD ve Hindistan’a kıyasla Türkiye'deki ölüm oranları bu üç ülkeden oldukça yüksektir [17]. Türk Mühendis ve Mimar Odaları Birliği’nin (TMMOB) 2010 yılında hazırladığı “Madenlerdeki İş Kazaları” raporunda 2008 yılındaki işletmelerde üretilen milyon ton taş kömürü başına düşen ölüm oranı, Türkiye Taşkömürü Kurumu’unda \%4.41 iken özel sektörde \%11.50, Çin'de \%1.27 ve ABD’nde \% 0.02 'dir [17]. 
1949-2009 yılları arasında Çin'de meydana gelen ölümcül kömür madeni kazaları incelendiğinde ölüm oranlarının giderek azaldığı tespit edilmiştir. Ancak Çin’de 1960 yılında kömür tozu patlaması nedeni ile 684 kişinin öldüğü kaza rapor edilen en ölümlü kazalardan biri olarak belirtilmiştir [9]. Güney Afrika'da maden kazaları üzerine yapılan çalışmada kaza risklerinin kestirimi, yapay sinir ağları modeli kullanılarak incelenmiştir. Bu çalışmada kömür madenlerinde ölümlü kazaların yıllar geçtikçe azaldığı ancak istenilen düzeye henüz ulaşılmadığı belirtilmiştir [18]. SAWS (Çin), MSHA (ABD) ve SGK (Türkiye) verilerine göre kömür madenlerinde milyon ton başına düşen ölümler 2001-2013 yılları arasında Çin ve ABD'de sistematik olarak düşerken Türkiye'de herhangi anlamlı bir eğilim göstermemiştir. [12]. Endonezya'da 2011-2016 yılları arasında yeraltı madenlerinde gerçekleşen kazaların dağılımı poisson dağılımı ile belirlenmiştir [19]. Hindistan'daki madenlerde gerçekleşen kazalar bulanık modelleme ile incelendiğinde çalışanların deneyimi, yaşı ve çalışma vardiyasının önemli olduğu bulunmuştur [20]. Avusturalya'nın 2016-2017 yılları arasındaki kaza ve yaralanma istatistikleri incelendiğinde, kömür kazalarının yıllar bazında azalma göstermesine rağmen yine de oranının çok yüksek olduğu tespit edilmiştir [21].

\section{B. Türkiye ve Dünyada Maden Kazalarının Nedenleri}

Türkiye ve dünyada yeraltı veya yerüstü maden kazalarını inceleyen çeşitli çalışmalarda birçok neden tespit edilmiştir. Türkiye'de yapılan çalışmalarda genellikle maden kazalarına ait nedenler belirlenmiş ve bu nedenlere ait oranlar verilmiştir. Dünya'daki maden kazalarının nedenleri incelendiğinde daha çok kaza nedenlerinin modellenmesine ağırlık verilmiştir.

2000 yılından başlayarak günümüze kadar olan Türkiye'deki maden kazalarının nedenlerine bakıldığında ölümlü kazaların daha çok grizu patlaması ve göçük nedeniyle olduğu tespit edilmiştir. Tunçbilek yeraltı kömür madeninde kazaların \%28'i göçük nedeniyle meydana gelmiştir [13]. Maden ocaklarında meydana gelen patlamalar ve yangınların nedenleri araştırıldığında; genel nedenlere benzer şekilde üretim yönteminin gerekliliklerinin tam olarak yerine getirilmemesi, üretim plan ve projesinin bulunmaması ve havalandırmadaki eksiklik ve aksaklıklar ilk sıralarda yer almıştır [22,23]. Yeraltı kömür madenlerinde çatı düşmelerine bağlı riskin yönetilmesi için üssel ve poisson dağılımı kullanılarak maliyet fayda analizi ile bir risk ve karar analizi yöntemi önerilmiştir [24]. Modern yöntemlerin kullanıldığı maden ocağı ile klasik yöntemlerin kullanıldığı maden ocağının karşılaştırılmasında, yeni teknolojilerin kullanılmasının klasik yöntemlere göre hem verimliliği arttırdığı hem de kazalar sonucu zarar gören kişi sayısını azalttığı tespit edilmiştir [25,23]. Maden ocaklarında kullanılan sistemlerin ve teknolojilerin, kazaların meydana gelmesi ve ölüm oranlarının seviyesi ile ilişkili olduğu görülmüştür. Ayrıca kazalar ve ölümlerin nedenleri arasında, havalandırma sistemlerindeki sorunlar, kaçış yolları yetersizliği, kişisel koruyucu donanımların yetersizliği gibi altyapı ve teknolojik sorunlar da belirtilmiştir [26]. Genel olarak bakıldığında Türkiye'de son yıllarda karşılaşılan ölümlü maden kazalarının nedenleri grizu patlaması, kömür tozu patlaması, göçük, ocak yangınları, su baskını, şev kayması, makine \& teçhizat donanımı veya trafik (vagon, sıkışma, kamyon...) biçiminde belirtilmiştir [12,27]. Buna ek olarak Türkiye'deki kömür kazalarına ait nedenler teknik olarak listelenmiştir [28]. 1983-2015 yılları arasında Türkiye'deki kömür madenlerinde meydana gelen 19 kazada yaklaşık 1000 madenci grizu patlaması, göçük, heyelan, yangın ve su baskını gibi nedenlerle hayatını kaybetmiştir [8].

Son yıllarda dünyada meydana gelen maden kazalarının nedenleri incelendiğinde, kazaların modellenmesi, ilişkilen- 
dirilmesi ve yeni yöntemlerin bu veriler üzerinde uygulamasının yapıldığı görülmüştür. Kömür madenlerinde meydana gelen kazalar veri madenciliği yaklaşımları kullanılarak bireye özgü faktörler, imkanlar, gaz, toz, çevresel ve işletme \& yönetimsel faktörler olarak incelenmiştir [29]. Maden güvenliği ve sağlık idaresi veri tabanı kullanılarak olası tehlikeler ile ilgili güvenlik standart ihlalleri incelenmiş ve bunun sonucunda madenlerdeki büyük yangın ve patlama tehlikelerinin neden olduğu riskler analiz edilmiştir [30]. ABD'nde 1970'lere kadar olan maden kazalarının nedenleri, yangın, patlatma, personel \& malzeme taşımacılığı, göçük, gaz ve su basması iken 1970'den günümüze insan faktörü de devreye girmiştir [31]. İspanya genel enerji ve madencilik idarisinden alınan yeraltı ve yerüstünde 1996-2006 yılları arasında gerçekleşen ciddi ve ölümlü kazaların sınıflandırma yöntemine göre \%67.5'i ekipmanın yönetim ve personel kaynaklı kötü bakılmasından veya yanlış kullanılmasından, \%21.7’si makinelerin, aletlerin ve kişisel koruyucu ekipmanların kötü bakımı ve tasarımından geldiği tespit edilmiştir [32]. Güney Afrika'da ölümlü maden kazalarının modellenmesinde, göçük, kullanılan ekipmanlar ve çalışanların yaşına bağlı lojistik regresyon analizi kullanılmıştır [33]. Çin'de 2001-2010 yılları arasında meydana gelen ölümlü kömür madeni kazaların \%44.97’si gaz patlamasından, \%16.87'si su basmasından, \%11.96'sı kömür patlamasından, $\% 8.46$ 'sı ise çatı çöküntülerinden meydana geldiği bulunmuştur [10]. İş sağlığı içinde yer alan insan sağlığı ile ilgili riskleri kontrol etmek ve o risklerle ilgili karar vermek için İran'da üç madende madencilerin güvenliğini incelemede coğrafik, elektrik, mekanik, kimyasal, çevresel, insana ait sosyal, kültürel ve yönetimsel riskler incelenerek fuzzy modeli kurulmuştur [11]. Bu modele göre madendeki yaralanmalara ve ölümlere, gazlardan kaynaklı patlama, elektrik arızası sonucu yangın, vagonların yoldan çıkması ve havalandırmadaki gibi mekanik problemler, işçilerin eğitimsizliği ve yönetimsel hataların neden olduğu bulunmuştur [11]. Çin'de kömür maden ocaklarında 2006-2010 yılları arasında gerçekleşen ölümcül gaz kazaları incelendiğinde bu gaz kazalarının aralığının dağılımı üssel olarak elde edilmiştir [34]. Avusturalya, Çin, Hindistan, Güney Afrika ve ABD'ndeki yeraltı ve yerüstü ölümlü maden kazalarının patlatma, kayma ve göçük nedenlerine bağlı olarak karşılaştırılmalı yapılan çalışmasında, 2006-2010 yılları arasında Çin ve Hindistan'da ölümlerin çok daha fazla olduğu bulunmuştur [35]. Yapısal eşitlik modellemesine göre Çin'de meydana gelen kazalar, operatör davranışlarının, tüm ekipmanların, çevrenin ve de idare tarafindan belirlenen kural ve düzenlemelerin güvensiz koşulları için dört kategoride belirlenmiştir [36]. Çin'de gerçekleşen ölümcül gaz kazalarının 2000-2014 yılları arasında yapılan çalışmasında \%23'ünün yasal olmayan patlatma çalışmaları sırasında gerçekleştiği bulunmuştur [37]. Yeraltı ve yerüstü Hindistan madenlerinde çalışan işçilerin güvenliğini araştırmada risk belirlemek için kurulan fuzzy modelinde işçilerin deneyimi, yaşı ve vardiyası işçilerin risk seviyesini belirlemede etkili olmuştur [20]. İspanya'da 2005-2015 yılları arasında yeraltı kazalarına ilişkin yapılan çalışmada kaza nedenleri olarak düşme, göçük ve çalışan sayısının fazlalığı olarak belirlenmiştir [38].

\section{VERİ KAYNAĞI VE YÖNTEM}

\section{A. Veri Kaynağı}

$\mathrm{Bu}$ araştırmada yer alan veriler 2009-2011 yılları arasında Türkiye Maden Mühendisleri Odası (TMMO) tarafından yayınlanan "Madencilik Bülteni” süreli yayınlarının 88-99 numaralı sayılarından ve TMMO'nın kendisinin sektörden toplayarak oluşturmuş olduğu arşivlerinden derlenerek toplanmıştır.

\section{B. Yöntem}

Türkiye'de yeraltı işletme kömür ocaklarında belli bir 
212127272721212

sürede meydana gelen ölümlü kazaların incelenmesinde, iş kazalarına ilişkin faktörlerin Cox regresyon modeli ile çözümlenmesi ve varsayım kontrollerinin yapılması amaçlanmaktadır. Sağkalım çözümlemesinde kullanılan Cox regresyon modeli, bağımlı değişken, sansür ve risk faktörlerini oluşturan bağımsız değişkenler ile kurulur. Bu çalışmada kömür maden ocağında ölümlü kaza gerçekleşinceye kadar geçen süre, bağımlı değişken olarak belirlenmiştir. Cox regresyon çözümlemesi için kullanılacak olan sansür değişkeni, ölümlü kazanın gerçekleşmemesidir. Risk faktörleri ise işçi sayısı, gaz ölçüm koşulları, havalandırma koşulları, elektrik teçhizatının uygunluğu, kömür tozunun miktarı, patlatmaya uygunluk, kişisel donanım ve teçhizatın uygunluğu olarak belirlenmiştir.

\section{Sağkalım Çözümlemesi}

Sağkalım çözümlemesi, ilgilenilen bir olayın belirli bir başlangıç noktasından itibaren gerçekleşmesine kadar geçen sürelerden oluşan verilerin çözümlenmesinde kullanılır. Bu süreler genellikle "başarısızlık" zamanı olarak adlandırılır. Bu çözümleme yöntemi biyoistatistik (kişinin bir hastalıktan kurtuluncaya veya ölünceye kadar geçen süresi), ekonometri, psikometri, iktisat, kalite (elektronik bir parçanın bozuluncaya kadar geçen süresi), maliye ve risk analizi (maden kazası oluncaya kadar geçen süre, otobüs şoförünün kaza yapıncaya kadar geçen süresi) gibi çeşitli bilim dallarında ve alanlarında kullanılır.

Sağkalım verilerinin çözümlenmesinde karşılaşılan problemlerden biri gözlemlediğimiz bazı verilerin başarısızlık zamanlarının gözlenememiş olmasıdır. Bu süreçte olay meydana gelmeyebilir veya çalışma süresi boyunca birimler izlenememiş olabilir ya da ilgilenilen olay dışında başka bir nedenle çalışmadan vazgeçilmiş olabilir. $\mathrm{Bu}$ verilere “sansürlü” adı verilir. Sağkalım verileri, sansürlü verilere sahip olmasından dolayı klasik istatistiksel çözümlemeleri kullanmazlar ve genellikle de normal dağılım göstermezler.

Sağkalım çözümlemesinde, ilgilenilen olayın çözümlenmesine ilişkin farklı yaklaşımlar bulunmaktadır. Bu yaklaşımlardan birincisi; eğer sağkalım verilerinin dağılımı biliniyorsa (normal, exponential, Weibull, gamma vb...), sağkalım dağılımına ait fonksiyonlar sayesinde parametre tahminleri ve hipotez testleri kolaylıkla yapılır. İkinci yaklaşım ise; herhangi bir dağılım varsayımı gerektirmeyen yani parametrik olmayan yöntemler (yaşam tablosu, KaplanMeier) yardımıyla tahminde bulunmaktır. Sonuncu yaklaşım ise, başarısızlık zamanlarının yanıt değişkeni olarak kabul edildiği ve bu değişkeni açıkladığı düşünülen diğer değişkenlerin de analizde yer aldığı regresyon (Cox) yöntemidir. Ancak tüm bu yöntemlerin kullanılabilmesi için sağkalım analizi fonksiyonları kullanılması gerekir.

Sağkalım analizi fonksiyonları "sağkalım fonksiyonu, $S$ $(t)$ ", "olasılık yoğunluk fonksiyonu, $f(t)$ " ve "hazard (tehlike) fonksiyonu, $h(t)$ " olarak bilinir. Bu fonksiyonlar matematiksel olarak birbirinden elde edilebilir. Sağkalım süresi $T$ rassal değişkeni ile gösterildiğinde $T$ nin alabileceği değerler $t$ ile gösterilir. Olasılık yoğunluk fonksiyonu, $f(t)$, birim zamanda ölüm veya başarısızlık olaylarının oranını gösterir.

Sağkalım fonksiyonu, $S(t)$, sağkalım süresinin $t^{\prime}$ den büyük olması olasılığı olup, olasılık fonksiyonu, $F(t)$ ile de gösterilebilir $(S(t)=P(T>t)=1-F(t)=1-P(T \leq t) ; 0<$ $t<\infty)$. $S(t)$, azalan ve sürekli bir fonksiyondur ve aynı zamanda $t=0$ iken, $S(t)=S(0)=1 ; t=\infty$ iken; $S(t)=S(\infty)=$ 0 olur.

Hazard fonksiyonu ise bir birimin $T=t$ zamanına kadar yaşaması koşulu altında, $\Delta t \rightarrow 0$ iken, o birimin $[t, t+\Delta t]$ aralığında yaşamın sona ermesi oranıdır. Hazard fonksiyonu $h(t)=f(t) / S(t), \quad 0<t<\infty$ ile gösterilir. Hazard fonksiyonu, her bir zaman noktasındaki başarısızlık riski- 
nin bir tanımıdır. Hazard fonksiyonu, $t$ yaşına kadar yaşamını sürdürdüğü bilinen bir birimin var olan başarısızlık riskini dikkate alır. Aynı zamanda farklı grupların karşılaştırılmasını yaparken bu fonksiyonu temel almış modeller sansürlü verilerin varlığında iyi çalışır [39].

\section{Yaşam Tablosu}

Yaşam tablosu yöntemi, araștırmacı tarafından belirlenen zaman aralıklarını gruplayarak değerlendiren bir yöntemdir. Gözlemler çalışmaya araştırmanın sürdüğü herhangi bir zamanda katılabilirler. Gözlemler süreç (bir yıl, bir ay, vb...) sonuna kadar normal olarak izlenebilecekleri gibi belli bir anda kaybolabilir, çalışmadan çıkarılabilir veya araştırılan özelliği gösterir duruma girebilirler. Yöntem başlangıçta \%100 olan yaşam olasılığının belirli zamanda azaldığı yeni yaşama olasılıklarını belirler.

\section{Kaplan-Meier Yöntemi}

Kaplan ve Meier 1958 yılında sağkalım süresine ilişkin fonksiyonunun tahminini yapabilmek için Kaplan-Meier (Product-Limit) yöntemini geliştirmişlerdir. Kaplan-Meier yöntemi gözlemci tarafından belirlenen örneklemde gözlemlediği olayın gerçekleşme sıklığının, oranının ya da olasılığının zamana bağlı değişimini analiz eden bir yöntemdir. Gruplar arasında sağkalım fonksiyonlarını karşılaştırmak için kullanılır ve olay zamanları arasında belli bir sıra izlenmemektedir. Bu yöntem sansürlü verilerin ortaya çıktığı zamanın kesinlikle bilinmesini ve ona göre işleme alınmasını, gözlemlerin çalışmaya katılma tarihlerini ve de olayın gerçekleştiği zamanın bilinmesi gerektiğini dikkate alir.

Kaplan-Meier yöntemi, tablo ve grafikleri kullanarak yaşam ve hazard fonksiyonlarını oluşturulan koşullu olasılığa dayanan bir yöntemdir. Kaplan-Meier yönteminin tahmin aşamaları şu şekilde sıralanabilir.

i. Zaman aralığ $[0, t)$ alt aralıklara $\left[t_{0}=0, t_{1}\right),\left[t_{1}, t_{2}\right), \ldots$, $\left[t_{k-1}, t_{k}=t\right)$ şeklinde bölünür.

ii. Her bir $\left(t_{j-1}, t_{j}\right)$ aralığı için $p_{j}=\frac{P_{j}}{P_{j-1}}$ oranı tahmin edilir. Bu oran $t_{j-1}$ 'den sonra yaşadığ 1 bilinen bir bireyin $t_{j}$ 'den sonrada yaşama olasılığı olarak tanımlanan koşullu olasılık olup aşağıdaki gibi ifade edilir.

$$
p_{j}=P\left(T>t_{j} \mid T>t_{j-1}\right)=\frac{P\left(T>t_{j}\right)}{P\left(T>t_{j-1}\right)}=\frac{P_{j}}{P_{j-1}}
$$

Eğer $t$ bir bölme noktası ise, kitle için $P(t)=S(t)=P(T>t)$ oranı $t^{\prime}$ den önceki tüm aralıklar için tahmin edilen $p_{j}$ 'lerin çarpımı olarak tahmin edilir. Başlangıç zamanında hiçbir zaman aralığının aynı zamanda sansürlü ve ölümü durumu aynı anda içermediği kabul edilir.

$$
P=P\left(T>t_{j}\right)=S\left(t_{j}\right) j=1, \ldots, k+1 \text { ve [1] formülünü }
$$
kullanarak olasılıklar aşağıdaki gibi elde edilir.

$$
\begin{aligned}
& j=0 \text { için, } S\left(t_{0}\right)=S(0)=P_{0}=1, \\
& j=1 \text { için } p_{1}=\frac{P_{1}}{P_{0}} \rightarrow P_{1}=p_{1}, \\
& j=2 \operatorname{için~} p_{2}=\frac{P_{2}}{P_{1}} \rightarrow P_{2}=p_{2} p_{1}, \\
& \cdots \\
& P_{j}=\prod_{j=1}^{k} p_{j}
\end{aligned}
$$

iii. $n_{j}=\left[t_{j-1}, t_{j}\right)$ zaman aralığında risk altında olan birey sayısı ve $d_{j}=\left[t_{j-1}, t_{j}\right)$ zaman aralığında gözlenen ölüm sayısı olarak tanımlanırsa $\widehat{P}_{J}=\frac{n_{j}-d_{j}}{n_{j}}$ olarak tahmin edilir. Bu tahmine Kaplan-Meier tahmini adı verilir ve aşağıdaki gibi gösterilir [40].

$$
\widehat{S_{t}}=\hat{P}(t)=\prod_{j=1}^{k} \frac{n_{j}-d_{j}}{n_{j}}, \quad t_{k}=t
$$

Bununla birlikte, herhangi bir alt zaman aralığı yalnızca sansürlü zamanlarını içeriyorsa $\widehat{p}_{J}=1$ olacaktır. Ayrıca en büyük gözlem sansürlü ise bu tahmin kullanılamaz [41].

Sağkalım çözümlemesindeki özel istatistiklerde en çok kullanılan medyan (ortanca) sağkalım süresi olmaktadır. Medyanın basit bir tahmini, zamanın $t, \hat{S}(t)=0.5$ olduğu 
Kaplan-Meier yöntemiyle sağkalım eğrisinden tahmin edilebilmektedir. Bununla birlikte eğer gözlemlerin \%50'den fazlası sansürsüzse ve en büyük gözlem sansürlüyse, medyan sağkalım süreleri tahmin edilememektedir [42].

\section{Log-Rank testi}

Farklı gruplardaki yaşam sürelerini karşılaştırmak için log-rank testi kullanılır. Ki-kare dağılımına dayanan logrank testinde $H_{0}$ hipotezi kitle yaşam eğrileri arasında fark olmadığını iddia eder. Log-rank testi için test istatistiğinin hesabı aşağıdaki gibidir.

$$
\chi^{2}=\sum_{j=1}^{g} \frac{\left(G_{j}-B_{j}\right)^{2}}{B_{j}} \sim \chi_{g-1}^{2} \quad j=1, \ldots, g
$$

Burada $G$, gözlem değeri, $B$, beklenen değer ve $g$, grup sayısı olarak ele alınır. İki grup için beklenen değerin formülü ise aşağıdaki gibi hesaplanır.

$$
B_{2}=\sum_{i=1}^{k} \frac{d_{i}}{r_{i}} r_{2 i}
$$

Burada $d$, ölenlerin sayısı, $r$, yaşayanların sayısı, $r_{2}, 2$. grupta yaşayanların sayısı ve $k$ kişi sayısıdır. Grup sayısı ikiden fazla olduğu durumda genelleştirilmiş log-rank testi kullanılır.

\section{Cox Regresyon Yöntemi}

Regresyon çözümlemesi, bağımlı değişken üzerinde etkili olabileceği düşünülen bağımsız değişkenlerin etki düzeylerini ve biçimlerini ortaya koyan matematiksel bir yöntemdir. Klasik regresyon çözümlemesinde neden-sonuç ilişkisi araştırılırken bağımlı değişken ve sürekli bağımsız değişkenler normal dağılmalıdır. Ayrıca bağımlı değişkene ait hata terimleri de sıfir ortalama ve sabit varyans ile normal dağılmalıdır. Bağımsız değişkenler arasında ilişki olmaması gerekmektedir. Ancak ilgilenilen olaya ait bağımlı değişken olan sağkalım süresi normal dağılım göstermiyorsa ve gözlemler arasında ilgilenilen olayın gerçekleşmediği gözlemler bulunuyorsa, klasik regresyon çözümlemesi yerine Cox regresyon çözümlemesi kullanılır.

Sağkalım çözümlemesinde kullanılan Cox regresyon yöntemi, ölüm risklerini ortaya koyması açısından güçlü istatistiksel bir yöntemdir. Ancak bu yöntemin kullanılması için aşağıda belirtilen varsayımların sağlanması gerekmektedir.

i. Bağımsız değişkenlerin sağkalım fonksiyonu üzerindeki etkileri logaritmik olarak doğrusaldır.

ii. Bağımsız değişkenlerin log-lineer fonksiyonu ile sağkalım fonksiyonu arasında çarpımsal bir ilişki vardır.

iii. Hazard oranı zamana göre değişmez, sabit kalır. Bu varsayıma "oransal hazard varsayımı" da denir.

Cox (1972) tarafından geliştirilen

$$
h(t, x)=h_{0}(t) \exp \left(\beta^{\prime} x\right)
$$

regresyon modelinde $x$, ortak değişkenler vektörü $\left(x_{1}, \ldots, x_{k}\right), \beta$,regresyon katsayı vektörü, $h_{0}(t)$ ise $x=0$ olan bir birimin "temel hazard fonksiyonu" olarak tanımlanmaktadır. Bu modelde $h_{0}(t)$ ile ifade edilen hazard fonksiyonuna, $t$ zamanındaki doğal olarak var olan hazard (ölüm, tehlike) fonksiyonu adı da verilir ve bu fonksiyon her yaşın taşımış olduğu ölüm riskidir. $\exp \left(\beta^{\prime} x\right)$ ise ortak değişkenlerin değerlerine ve regresyon katsayılarına bağlı olarak değişen hazard (ölüm, tehlike) riskini ifade etmektedir.

$\beta$ katsayılarının hesaplanmasında Newton-Raphson algoritması kullanılarak en çok olabilirlik yöntemi ile logaritmik benzerlik fonksiyonunu en büyüklüyerek tahmin yapılır. Daha sonra bu katsayıların önemliliği de "olabilirlik oran testi” ya da "Wald testi” yöntemleri ile araştırılır.

Cox regresyon modelinde temel hazard fonksiyonu, zamanın bir fonksiyonunu içerirken, üssel kısımda yer alan değişkenler ise zamanın bir fonksiyonu olmamaktadır. Bir 
başka deyişle, bu değişkenler zamandan bağımsızdır. Ancak bazen zamana bağlı değişkenlerde olabilir bu durumda zamana bağlı Cox regresyon modeli kullanılmalıdır. Tabakalı Cox regresyon modeli ise oransal hazard varsayımı sağlanamadığında Cox regresyon modeli yerine kullanılan ve de varsayımı sağlamayan değişkene göre tabakalandırılmış olan regresyon modelidir. Değişkeni içermeyen (etkileşimin olmadığı) ve incelenecek değişkenin tabakalarını içeren (etkileşimin olduğu) regresyon modelleri kurulur. Kurulan regresyon modellerinin "olabilirlik oran testi" sonucunda etkileşim olduğu veya olmadığı modeller seçilir $[43,44,45]$.

\section{Oransal Hazard Varsayımı}

Cox regresyon yönteminin en önemli varsayımlarından biri olan "oransal hazard varsayımı", hazard oranının zamana karşı sabit olması ya da bir bireyin hazardının diğer bireyin hazardına orantılı olması anlamına gelmektedir $[43,46]$. Oransal hazard varsayımının incelenmesi için kullanılan yöntemler, grafiksel yöntemler (gözlenen ve beklenen yaşam eğrileri, arjas grafikleri, $\log (-\log )$ yaşam eğrileri), zamana karşı açıklayıcı değişkenlerin kullanıldığı yöntem ve Schoenfeld artıkları ile yaşam sürelerinin rankının korelasyon testidir. Grafiksel yöntemlerden,

- $S(t)$ ve $t$ arasında çizilen Kaplan-Meier ve Cox regresyon yöntemlerinden elde edilen gözlenen ve beklenen yaşam eğrileri birbirine benzerse,

- $\log (-\log )$ ve $t$ arasında çizilen $\log (-\log )$ grafiğinde yaşam eğrileri birbirine paralelse

- Birikimli hazard $H(t)$ ve $t$ arasında çizilen arjas grafiğinde eğim 1 veya 1'e çok yakın ve yaklaşık olarak doğrusal ise

oransal hazard varsayımı sağlanmış olur $[43,44,47,48]$.

Grafiksel yöntemlerden $\log (-\log )$ yaşam eğrilerinin karşılaştırılması, incelenen değişkenlerin farklı kategorileri üzerinden yapılır. Gözlenen ve beklenen yaşam eğrilerinde ise doğrudan bir karşlaştırma vardır. Arjas grafiği ise alternatif modellerin tahminine gereksinim duymadığından ve sadece parametre tahmininde kullanılan kısmi olabilirlik ifadesindeki niceliklere benzer nicelikleri içerdiğinden kullanılması kolay bir yöntemdir. Grafiksel yöntemler içinde en uygun sonucu veren yöntemdir. Ancak tüm grafiksel yöntemler özneldir $[43,44,47]$. Bu yüzden mümkünse tüm yöntemlerin aynı anda bakılması ve buna göre karar verilmesi uygun olmaktadır.

Oransal hazard varsayımı için diğer bir yöntemde modelde zamana bağlı bağımsız değişkenlerin yer almasıdır. Bunun için zaman değişkeni yerine log (zaman) kullanılır. Test istatistiği her bir bağımsız değişken ve log (zaman) değişkeninin etkileşimi ile hesaplanır. Bu etkileşimlerin katsayıları önemsiz ise oransal hazard varsayımı sağlanmış olur [49]. Zamana bağlı bağımsız değişkenlerin kullanıldığı genişletilmiş Cox regresyon modeli ile zamandan bağımsız Cox regresyon modeli arasındaki farkın kullanıldığı olabilirlik oran test istatistiği ki-kare dağılımına bağlıdır. $\mathrm{Bu}$ testte $H_{0}$ hipotezi oransal hazard varsayımının sağlandığı yönündedir. Bu hipotez red edilirse oransal hazard varsayımı sağlanmamaktadır [43,49].

Oransal hazard varsayımının incelenmesi için Schoenfeld artıkları kullanılır. Schoenfeld artıkları zamana karşı çizilir ve bu artıklar açıklayıcı değişkenin gerçek değeri ile ağırlıklı risk skorlarının ortalaması arasındaki farktır. Çizilen Schoenfeld artıkları grafiği, yatay bir doğru etrafında (sıfır merkezli) rastgele bir şekilde dağılıyorsa oransal hazard varsayımı sağlanır [44,50]. Bununla birlikte belirli bir değişken için Schoenfeld artıkları ile bireylerin yaşam süreleri arasındaki korelasyon kullanılarak oransal hazard varsayımı istatistiksel olarak incelenebilir. Bu teste göre, oransal hazard varsayımının sağlanması için korelasyonun sıfıra 
yakın olması beklenmektedir. Bir başka deyişle bu test sonucuna ait $p$ değerlerine bakıldığında $H_{0}$ hipotezi red edilemezse oransal hazard varsayımının sağladığı kabul edilmektedir [43]. Ancak bu test istatistiği sürekli verilerde çalışmaktadır [43,51].

$\mathrm{Bu}$ yöntemlerden grafiksel yöntemler araştırmacılar tarafından öznel bulunmaktadır. Ancak bağımsız değişkenler kategorik ve kategori sayısı az ise grafiksel yöntemlerden yararlanılır ve böylece sonucu görmek daha kolay olur. Bununla birlikte Winnett ve Sasieni bağımsız değişkenler sürekli olduğunda Schoenfeld artıklarının kullanılmasını önermiştir [52].

\section{BULGULAR}

Bu bölümde 2009-2011 yılları için Türkiye Maden Mühendisleri Odası (TMMO) ve "Madencilik Bülteni" dergisinden alınan Türkiye'deki 70 yeraltı kömür maden ocağındaki ölümlü kaza gerçekleşinceye kadar geçen sürenin analizi yapılmıştır. Tablo 1'de bağımlı değişkenin (ölümlü kaza gerçekleşinceye kadar geçen süre, ay) ve risk faktörlerinin (iş̧̧i sayısı, gaz ölçüm koşulları, havalandırma koşulları, elektrik teçhizatının uygunluğu, kömür tozunun miktarı, patlatmaya uygunluk, kişisel donanım ve teçhizatın uygunluğu) tanımlayıcı istatistikleri verilmiştir. Uyum iyiliği testlerinden "Anderson Darling” testine göre kaza süresine ait bağımlı değişkenin Weibull, normal, lojistik, lognormal, loglojistik ve üssel gibi bilinen dağılımdan gelmediği tespit edilmiştir $\left(H_{0}=\right.$ Belirlenen dağıllımdan gelir, $p<0.05)$. Bu durumda sağkalım analizi için parametrik olmayan yöntemlerin uygulanabileceği ifade edilmiştir. Ayrıca çalışma içinde yer alan kömür ocaklarının sansür oranı literatürde kabul edilebilir bir oran olan \%21.4 olarak elde edilmiştir.

Tablo 1'e göre sınıflayıcı ölçek ile ölçülmüş işçi sayısı \%78.6 ile 100'ün üzerinde olarak tespit edilmiştir. Maden ocaklarının \%70'inde patlatma uygunluğu, \%67.2'sinde gaz ölçüm koşulları, \%54.3'ünde havalandırma koşulları ve \%62.9'unda ise elektrik teçhizatı uygun olarak bildirilmiştir. Kişisel donanım olarak bakıldığında bu maden ocaklarındaki işçilerin kişisel donanımının \%58.9 ile yapılmış

Tablo 1 Ölümlü Kaza Oluncaya Kadar Geçen Sürenin ve Risk Faktörlerinin Tanımlayıcı İstatistikleri (n=70)

\begin{tabular}{lclc}
\hline Risk Faktörleri & Frekans (\%) & Risk Faktörleri & Frekans (\%) \\
\hline iş̧̧i Sayısı & & Patlatma Uygunluğu & \\
\hline $0=(<100)$ & $15(21.4)$ & $\begin{array}{l}\text { 0=Uygun Değil } \\
\text { 1=Uygun }\end{array}$ & $21(30.0)$ \\
$1=(\geq 100)$ & $55(78.6)$ & $49(70.0)$ \\
\hline Donanım & & Gaz Ölçüm Koşulları & \\
\hline 0=Yapılmadı & $29(41.4)$ & 0=Uygun Değil & $23(32.8)$ \\
1=Yapıldı & $41(58.9)$ & 1=Uygun & $47(67.2)$ \\
\hline Havalandırma & & Elektrik Teçhizatı & \\
\hline 0=Uygun Değil & $32(45.7)$ & 0=Uygun Değil & $26(37.1)$ \\
1=Uygun & $38(54.3)$ & 1=Uygun & $44(62.9)$ \\
\hline Risk Faktörleri & Minimum & Maksimum & Ortalama \pm Sd \\
\hline Kaza Süresi & 1 & 0.90 & $7.47 \pm 2.45$ \\
Kömür Tozu Miktarı & 0 & $0.06 \pm 0.11$ \\
\hline
\end{tabular}


Tablo 2: Kaplan-Meier Yöntemi ile Risk Faktörlerine Ait Ortanca Yaşam Süreleri (OYS) ve Log-Rank (LR) Testi p-değeri

\begin{tabular}{|c|c|c|c|c|c|}
\hline Risk Faktörleri & OYS & p-değeri & Risk Faktörleri & OYS & p-değeri \\
\hline İşçi Sayısı & & & Patlatma Uygunluğu & & \\
\hline $0=(<100)$ & 6.00 & $0.000^{*}$ & 0=Uygun Değil & 8.00 & 0.077 \\
\hline $1=(\geq 100)$ & 8.00 & & $1=$ Uygun & 8.00 & \\
\hline Donanım & & & Gaz Ölçüm Koşulları & & \\
\hline $0=$ Yapılmadı & 8.00 & 0.585 & $0=$ Uygun Değil & 7.00 & $0.016 *$ \\
\hline 1=Yapıldı & 8.00 & & 1=Uygun & 8.00 & \\
\hline Havalandırma & & & Elektrik Teçhizatı & & \\
\hline $0=$ Uygun Değil & 8.00 & $0.007^{*}$ & $0=$ Uygun Değil & 8.00 & $0.030 *$ \\
\hline 1=Uygun & 9.00 & & $1=$ Uygun & 8.00 & \\
\hline
\end{tabular}

$* p<\alpha=0.05$

olduğu bildirilmiştir. Ölümlü kaza oluncaya kadar geçen sürenin en az 1, en çok 12 ay olduğu ve bu sürenin ortalamasının 7.47, standart sapmasının da 2.45 ay olduğu tespit edilmiştir. Ayrıca bu madenlerdeki kömür tozu miktarının 0 ile 0.90 arasında değiştiği ve de ortalamasının 0.06 olarak bulunduğu tespit edilmiştir (Tablo 1).

Sağkalım süresine ilişkin fonksiyonunun tahminini yapabilmek için kullanılan Kaplan-Meier yöntemi ile özet istatistiklerden “ortanca yaşam süresi”, tüm kategorik risk faktörleri için hesaplanmıştır (Tablo 2).

Tablo 2'de verilen Kaplan-Meier yöntemine göre ortanca yaşam süresi, işçi sayısı için 100 'ün altında olanlarda 6 ay iken üstündekilerde 8 ay olarak bulunmuştur. Havalandırma için uygun olmayan yeraltı maden ocaklarında ise ortanca yaşam süresi 8 ay iken uygun olanlarda 9 ay olarak elde edilmiştir. Ayrıca farklı gruplardaki yaşam sürelerini karşılaştırmak için kullanılan log-rank testi ile işçi sayısında $(\mathrm{p}=0.000)$, havalandırmada $(\mathrm{p}=0.007)$, gaz ölçüm koşullarında $(\mathrm{p}=0.016)$ ve elektrik teçhizatında $(\mathrm{p}=0.030)$ gruplar arası fark \%95 güvenle istatistiksel olarak elde edilmiştir. Kaplan-Meier sağkalım fonksiyonuna ait grafikler her kategorik risk faktörü için Şekil 1-6 arasında verilmiştir. Bu grafikler ile log-rank test sonuçlarının birbirini desteklediği görülmüştür.
Şekil 1: İşçi Sayısı için S(t) Grafiği

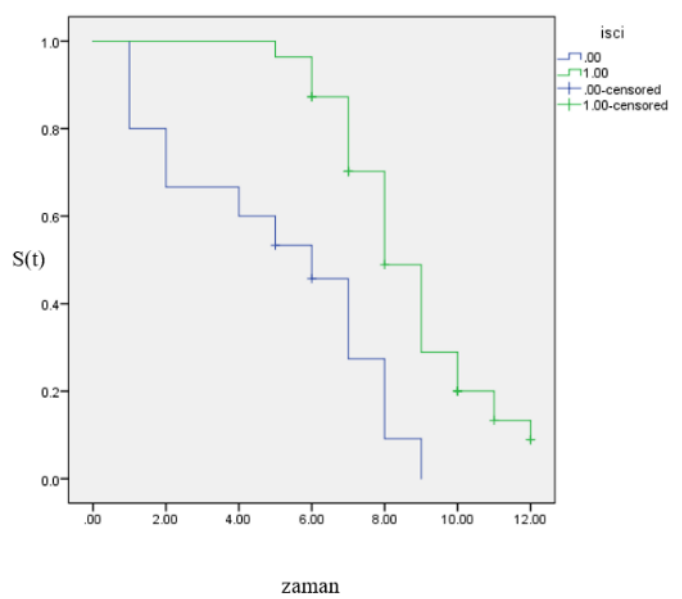

Şekil 2: Patlatma için S(t) Grafiği

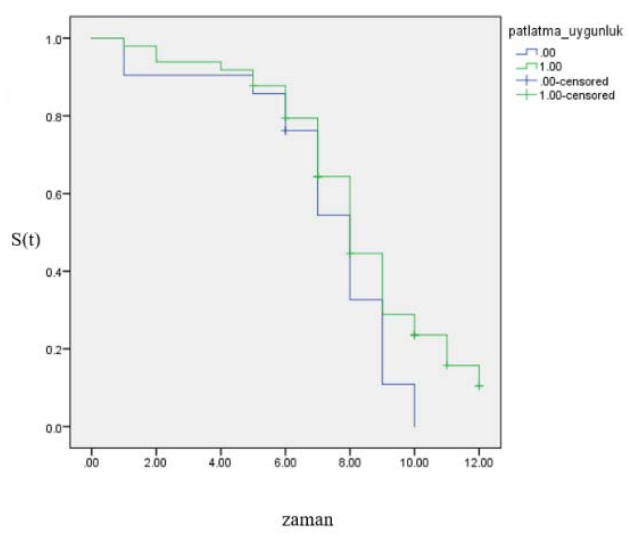


Şekil 3: Donanım için S(t) Grafiği
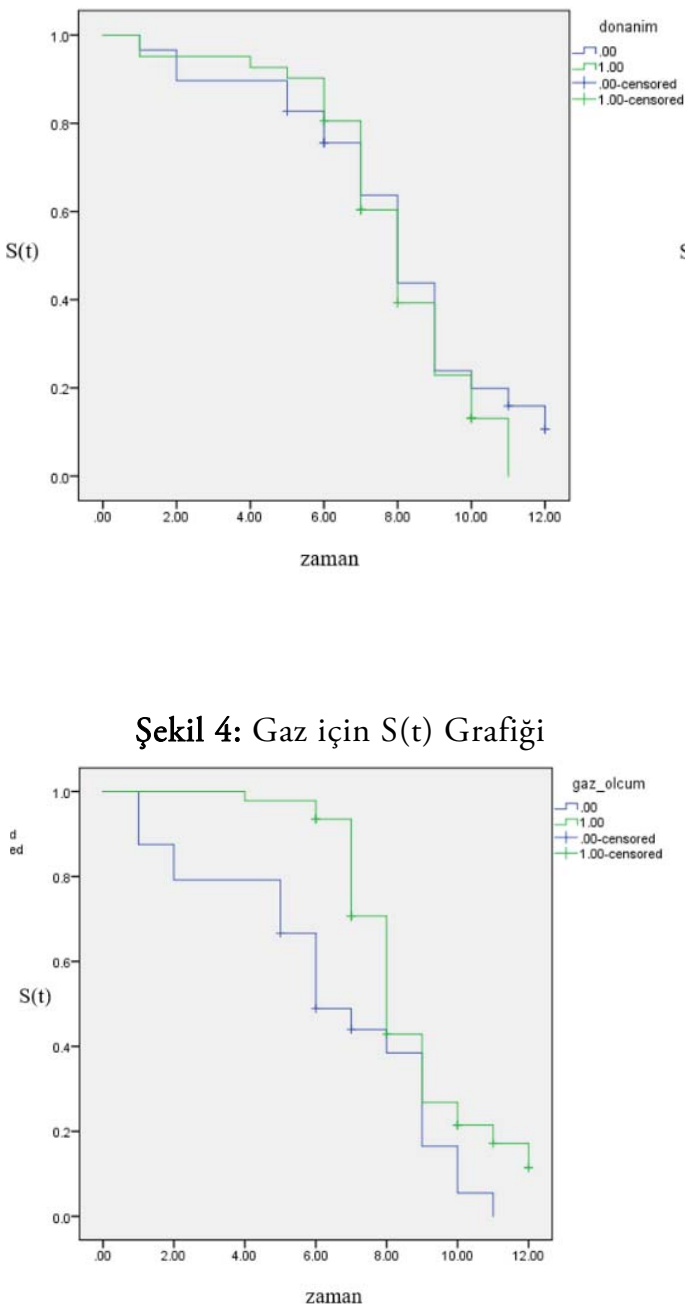

Şekil 5: Havalandırma için $S(\mathrm{t})$ Grafiği

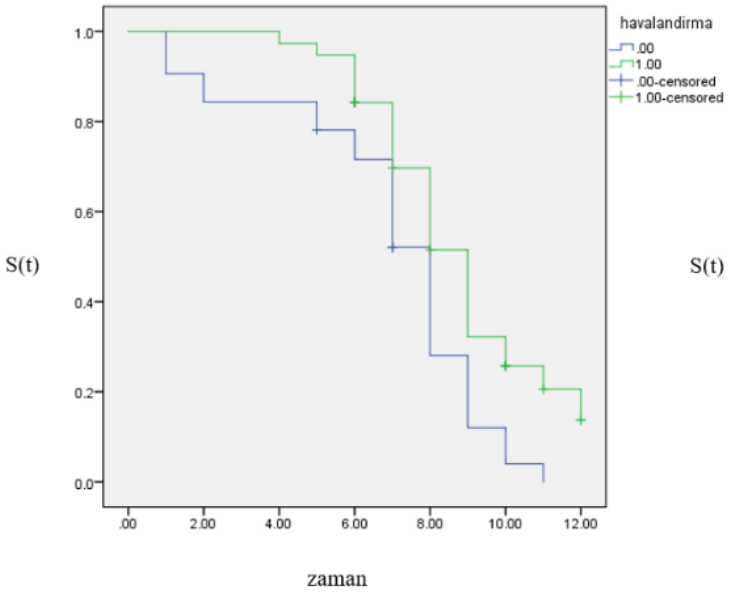

Şekil 6: Elektrik için $S(\mathrm{t})$ Grafiği

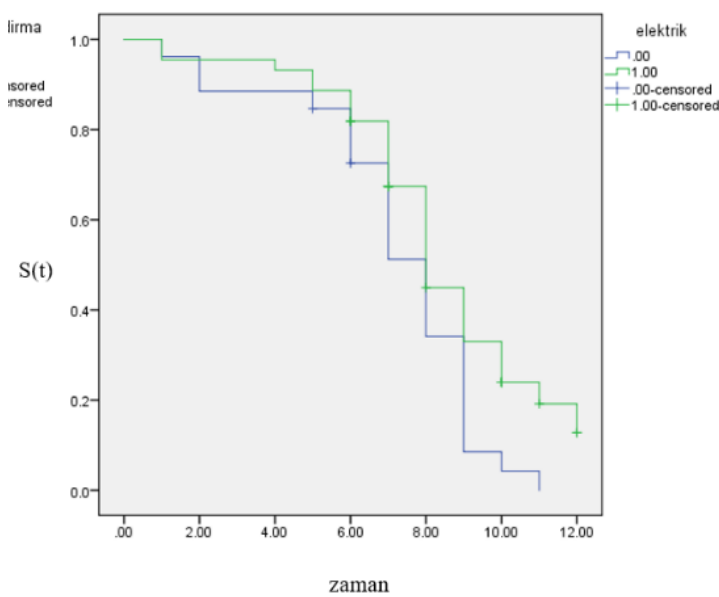

Madenlerde ölümlü kaza oluncaya kadar geçen süre için Kaplan-Meier yöntemi ile bütün kategorik risk faktörleri tek başına incelenmiş, log-rank testi ile de risk faktörlerinin grupları arasında farklılığın olup olmadığına bakılmıştır. Daha sonra tek başına incelenmiş tüm kategorik ve sürekli risk faktörlerinin ölümlü kaza oluncaya kadar geçen süre için modellenmesinde çok değişkenli Cox regresyon yöntemi kullanılmıştır (Tablo 3). Bu yöntem, ölüm risklerini ortaya koyması ve ilgilenilen değişkenin gerçekleşinceye kadar olan sürede etkili risk faktörlerinin bulunması açısından güçlü istatistiksel bir yöntemdir.

Kurulan çok değişkenli Cox regresyon modelinde geriye doğru eleme yöntemi kullanılarak olabilirlik oran testi sonucuna göre final Cox regresyon modeline ulaşılmıştır. Geriye doğru eleme yönteminde ilk elenecek risk faktörü, en yüksek p değerine sahip risk faktörü olup sırasıyla yüksek p değerli risk faktörleri modelden çıkartılmıştır. Buna göre çok değişkenli modelden çıkartılacak olan ilk risk faktörü "donanım" olup sırasıyla onu "patlatma" ve “elektrik" risk faktörleri takip etmiştir (p değerleri>0.05). Final Cox regresyon modelinde, yeraltı maden ocaklarında ölümlü kaza gerçekleşinceye kadar olan sürenin bağlı olduğu faktörler için "işçi sayısı", "havalandırma”, "gaz ölçüm koşulları" ve "kömür tozu miktarı" değişkenleri \%95 gü- 
Tablo 3: Çok Değişkenli Cox Regresyon Modeli

\begin{tabular}{lccccrr}
\hline Risk Faktörleri & Beta & SE & Wald & p-değeri & Exp(Beta) & \%95 G.A. \\
& & & & & & \\
\hline Işçi Sayısı & 1.18 & 0.40 & 8.69 & 0.003 & 3.25 & $1.48-7.14$ \\
Havalandırma & 0.75 & 0.31 & 5.60 & 0.014 & 2.12 & $1.62-3.87$ \\
Gaz & 0.60 & 0.30 & 4.00 & 0.046 & 1.82 & $1.01-3.28$ \\
Kömür Tozu & 2.56 & 1.09 & 5.52 & 0.019 & 12.96 & $1.53-109.90$ \\
Donanım & 0.07 & 0.33 & 0.04 & 0.834 & 1.07 & $0.56-2.03$ \\
Patlatma & 0.36 & 0.37 & 0.95 & 0.329 & 1.43 & $0.70-2.95$ \\
Elektrik & 0.30 & 0.31 & 0.98 & 0.322 & 1.35 & $0.74-2.47$ \\
\hline
\end{tabular}

$-2 \mathrm{LL}=362.114$

Tablo 4: Final Cox Regresyon Modeli

\begin{tabular}{lrrrrrr}
\hline Risk Faktörleri & Beta & SE & Wald & p-değeri & Exp(Beta) & \%95 G.A. \\
\hline İşç Sayısı & 1.42 & 0.35 & 16.48 & 0.000 & 4.16 & $2.09-8.28$ \\
Havalandırma & 0.70 & 0.29 & 6.02 & 0.014 & 2.02 & $1.15-3.55$ \\
Gaz Ölçüm Koşulları & 0.59 & 0.30 & 3.97 & 0.046 & 1.80 & $1.01-3.21$ \\
Kömür Tozu Miktarı & 2.25 & 1.04 & 4.67 & 0.031 & 9.52 & $1.23-73.52$ \\
\hline
\end{tabular}

$-2 \mathrm{LL}=364.317$

venle istatistiksel olarak anlamlı bulunmuştur ( $\mathrm{p}$ - rik risk faktörler için grafiksel yöntemlerden gözlenen ve değerleri<0.05) (Tablo 4).

Kurulan final Cox regresyon modelinde bu faktörlerin model oluşturabilmesi için oransal hazard varsayımını sağlaması gereklidir. Bu varsayımının incelenmesi için kategobeklenen yaşam eğrileri Şekil 7-9 arasında ve $\log (-\log )$ ile arjas grafikleri de Şekil 10-12 arasında verilmiştir. Hem kategorik hem de sürekli risk faktörleri için zamana bağlı bağımsız değişkenlerin kullanıldığı yöntem ile Schoenfeld artıkları Tablo 5 ve 6 'da elde edilmiştir.

Şekil 7: İşçi Sayısı için Gözlenen ve Beklenen Yaşam Eğrileri

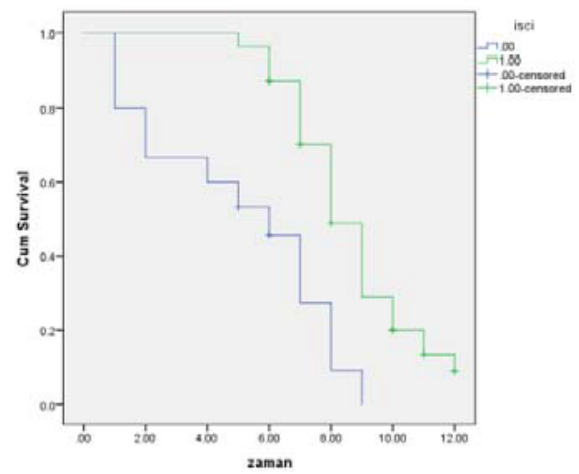

Kaplan-Meier Yaşam Fonksiyonu

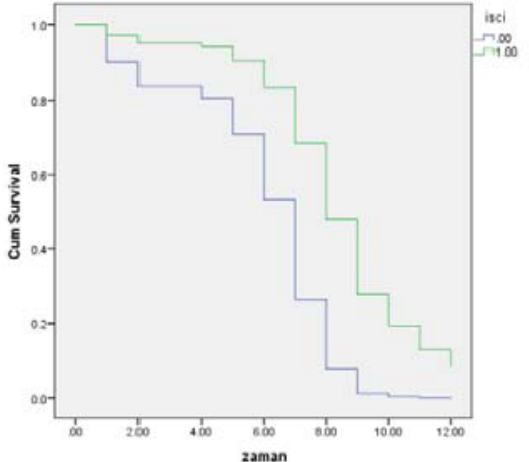

Cox Regresyon Yaşam Fonksiyonu 
Şckil 8: Havalandırma için Gözlenen ve Bcklenen Yaşam Eğrilcri

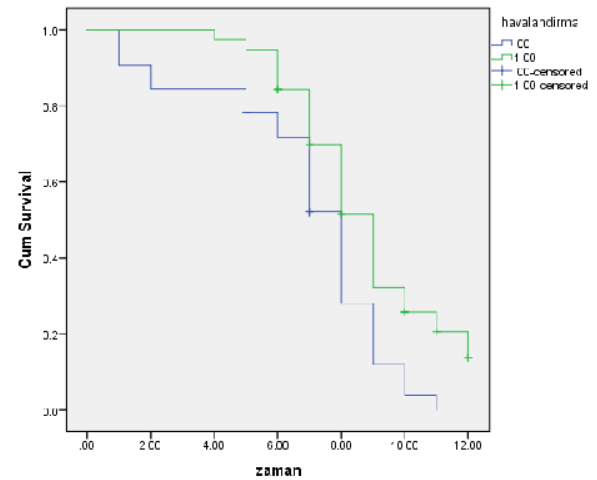

Kaplan-Mcicr Yaşam Fonksiyonu

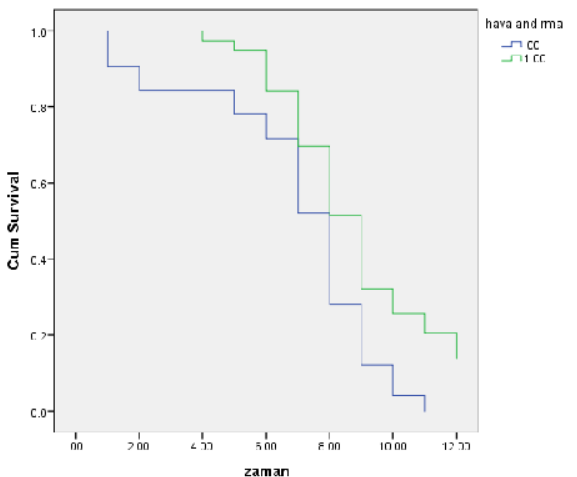

Cox Rcgresyon Yaşam Fonksiyonu

Şckil 9: Gaz Ölçüm Koşulları için Gözlencn ve Bcklencn Yaşam Eğrileri

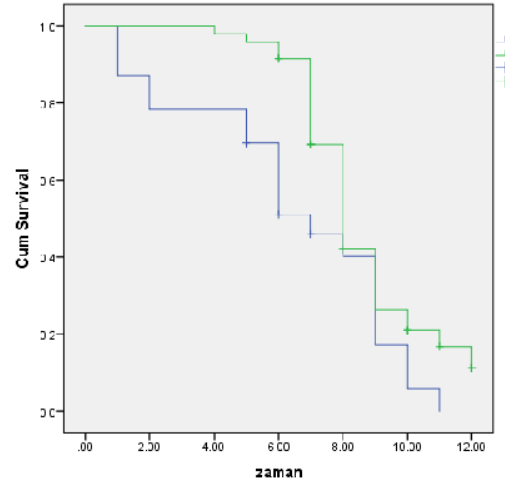

Kaplan-Meier Yaşam Fonksiyonu

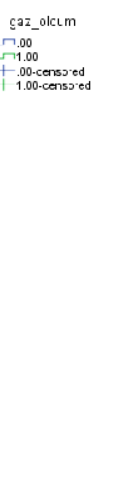

(1)

Grafiksel yöntemlerden ilk olarak kullanılan gözlenen ve beklenen yaşam eğrilerinin, "havalandırma" ve "gaz ölçüm koşulları” risk faktörleri için birbirine benzer oldukla-

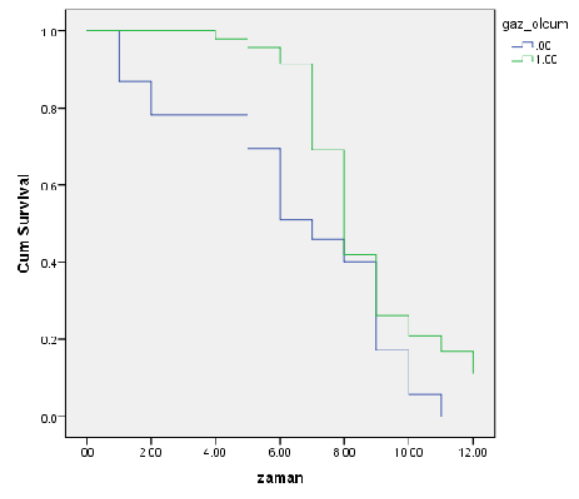

Cox Regresyon Yaşam Fonksiyonu.

r1, ancak "işçi sayısı" risk faktöründe buna benzer bir benzerliğin görülmediği tespit edilmiştir (Şekil 7-9).

Şekil 10: İşçi sayısı için Log(-log) Yaşam Eğrisi ve Arjas Grafiği
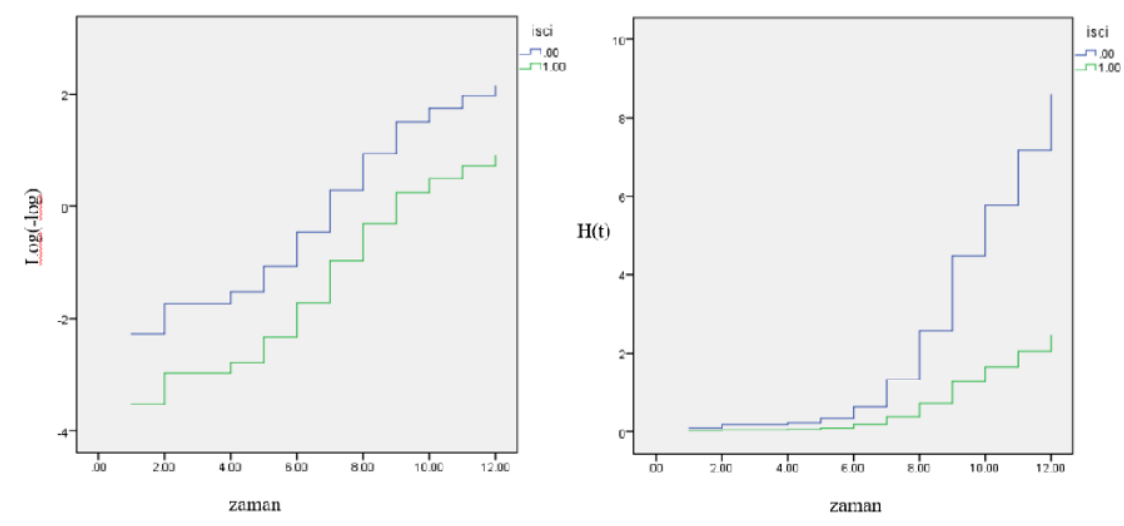
Şekil 11: Havalandırma için Log(-log) Yaşam Eğrisi ve Arjas Grafiği
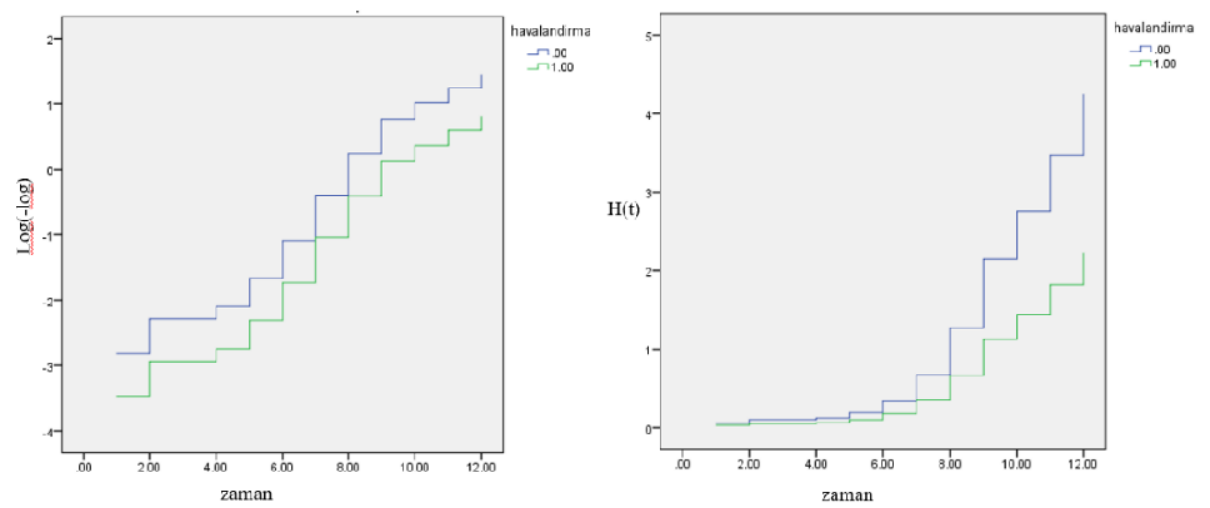

Şekil 12: Gaz Ölçüm Koşulları için Log(-log) Yaşam Eğrisi ve Arjas Grafiği

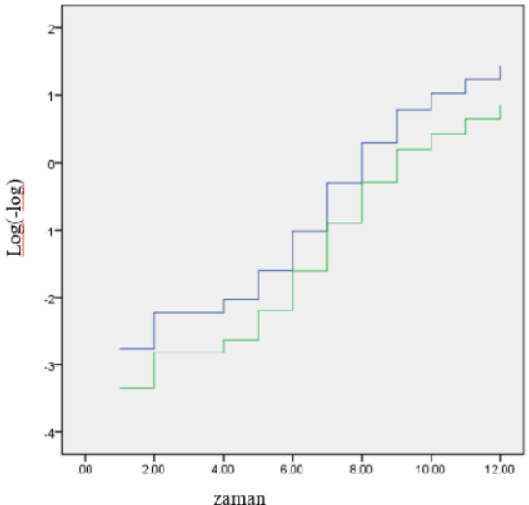

raman

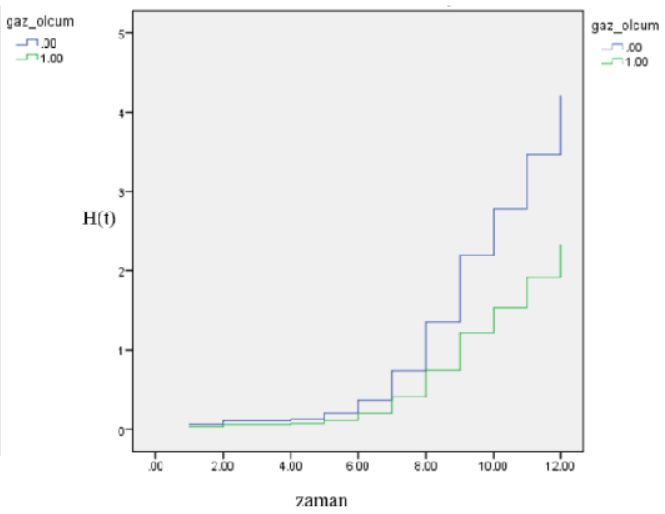

ce red edilemeyen $H_{0}$ hipotezi ile modelde yer alan risk

$\log (-\log )$ yaşam eğrilerinde risk faktörlerine ait yaşam eğrilerinin birbirine paralel olduğu görülmüştür. Arjas grafiğinde ise risk faktörlerinin eğiminin yaklaşık olarak 1'e yakın olduğu ve de doğrusal sayılabileceği ifade edilmiştir (Şekil 10-12).

Bununla birlikte tüm bu grafiksel yöntemlerde sonuçların öznel olduğu gerçeği unutulmamalıdır. Bu yüzden hem kategorik hem de sürekli risk faktörlerinin hepsi zamana bağlı bağımsız değişkenlerin kullanıldığı modeller ile istatistiksel olarak test edilmiştir. Zamanı bağlı bağımsız değişkenin yer aldığı modelde test istatistiği, her bir bağımsız değişken ile $\log ($ zaman) değişkeninin etkileşimi ile hesaplanmıştır. Bu etkileşimlerin katsayılarının önemsiz olması $H_{0}$ hipotezinin red edilememesini gerektirmektedir. Böyle-

faktörlerinin oransal hazard varsayımını sağladığı ifade edilmiştir (Tablo 5).

Tablo 5: Zamana Bağlı Bağımsız Değişkenler için

Kurulan Cox Regresyon Modeline ait p-değerleri

\begin{tabular}{llll}
\hline Risk Faktörleri & p-değeri & Risk Faktörleri & p-değeri \\
\hline İşçi Sayısı & 0.030 & Gaz Ölçüm Koşulları & $0.052^{*}$ \\
Havalandırma & $0.460 *$ & Kömür Tozu Miktarı & $0.818^{*}$ \\
\hline${ }^{*} p>\alpha=0.05$ & & &
\end{tabular}

Zamana karşı kurulan Cox regresyon modelinde "havalandırma", "gaz ölçüm koşulları" ve "kömür tozu miktarı” risk faktörlerinin oransal hazard varsayımını sağladığı $(p>0.05)$ ancak "işçi sayısı" ( $p=0.030<0.05)$ risk faktörünün sağlamadığı bulunmuştur.

Sürekli risk faktörlerinin oransal hazard varsayımı ince- 
lemesi için kullanılan diğer bir yöntem olan Schoenfeld artıklarında zamana karşı çizilen grafiğin rasgele (sıfır merkezli) olarak dağılması gerekmektedir. Bunun yanında kömür tozu miktarına ait Schoenfeld artıkları ile yaşam süreleri arasındaki korelasyon kullanılarak oransal hazard varsayımı istatistiksel olarak incelenmiştir (Şekil 13).

Şekil 13: Kömür Tozu Miktarına Ait Schoenfeld Artıkları

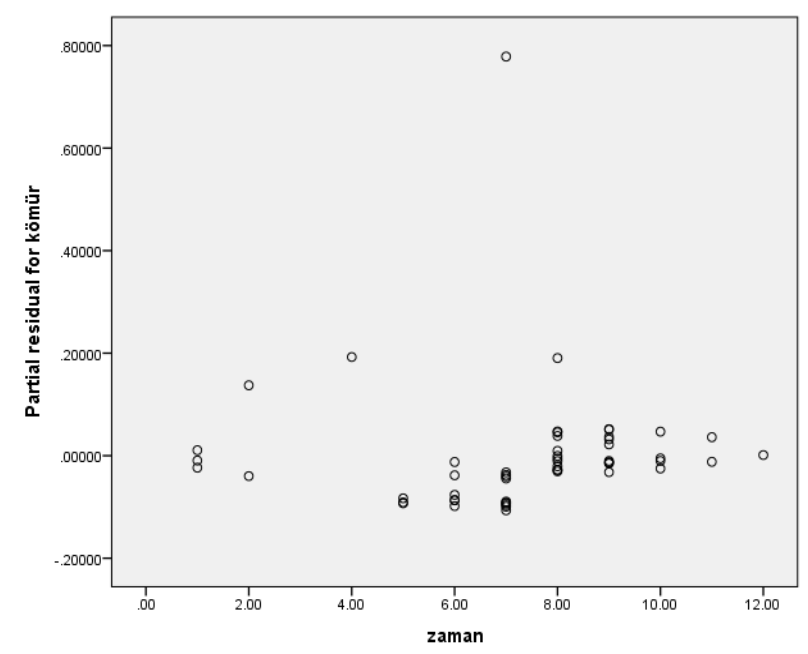

Schoenfeld artıkları ile bireylerin yaşam süreleri arasındaki korelasyon kullanılarak elde edilen testin sonucun $\mathrm{p}$ değerine bakıldığında $H_{0}$ hipotezinin red edilemediği ve oransal hazard varsayımının sağladığı kabul edilmektedir $(\mathrm{p}=0.124>0.05)$.

Cox regresyon yönteminin varsayımlarından “oransal hazard varsayımı" için yapılan tüm testler ve grafiklerin sonucu Tablo 6'da verilmiştir.

Tablo 6: Risk Faktörlerinin Oransal Hazard Varsayım Kontrolü

\begin{aligned} & \hline Yöntemler İşçi Sayısı Havalandırma Gaz Ölçüm Kömür \\ & Koşulları $\begin{array}{l}\text { Tozu } \\ \text { Miktarı }\end{array} \\ &$\hline\end{aligned}

\begin{tabular}{lccc}
\hline $\begin{array}{l}\text { Gözlenen ve } \\
\text { Beklenen } \\
\text { Log(-log) }\end{array}$ & $(-)$ & $(+)$ & $(+)$ \\
Eğrileri & $(+)$ & $(+)$ & $(+)$ \\
Arjas Grafikleri & $(+)$ & $(+)$ & $(+)$ \\
Zamana Bağlı & $(-)$ & $(+)$ & $(+)$
\end{tabular}

Schoenfeld Artıkları sadece kömür tozu miktarı için yapıımış ve de varsayımı sağlamıştır.

Risk faktörlerinin kullanıldığı Cox regresyon modelinde tüm varsayım kontrollerinin yapılması sonucunda sadece "işçi sayısı" $(\mathrm{p}=0.030<0.05)$ risk faktörünün oransal hazard varsayımını sağlamadığı bulunmuştur. Sağlamayan bu risk faktörü için tabakalı Cox regresyon modelinin yapılmasına karar verilmiştir. Tabakalı Cox regresyon modeli için "işçi sayısı" risk faktörünü içermeyen "etkileşimsiz model” ile tabakalara göre ayrılmış "etkileşimli model” sonuçları Tablo 7’de verilmiştir.

Tabakalı Cox regresyon modeline göre \%90 hata ile çalışıldığında etkileşimsiz modelde anlamlı bulunan değişkenlerin, etkileşimli modelde yer alan Tabaka 1'de anlamlı, Tabaka 2'de ise anlamsız olduğu tespit edilmiştir. Ayrıca -2LL değerleri dikkate alındığında,

Tablo 7: Tabakalı Cox Regresyon Modeli

Tabakasız

(Etkileşimsiz Model)

\begin{tabular}{lccccccc}
\hline Risk Faktörleri & Beta & $\mathbf{p}$ & $\mathbf{R R}$ & & Beta & $\mathbf{p}$ & RR \\
\hline Havalandırma & 0.60 & $0.032^{*}$ & 1.82 & $\mathrm{~T} 1$ & 1.53 & $0.086^{*}$ & 4.63 \\
& & & & $\mathrm{~T} 2$ & 0.51 & 0.116 & 1.66 \\
\hline Gaz Ölçüm Koşulları & 0.52 & $0.071^{*}$ & 1.68 & $\mathrm{~T} 1$ & 2.34 & $0.047^{*}$ & 10.38 \\
& & & & $\mathrm{~T} 2$ & 0.27 & 0.431 & 1.31 \\
\hline Kömür Tozu Miktarı & 2.08 & $0.025^{*}$ & \multirow{2}{*}{7.99} & $\mathrm{~T} 1$ & 8.80 & $0.050^{*}$ & 6622.50 \\
& & & & $\mathrm{~T} 2$ & 1.79 & 0.118 & 5.96 \\
\hline -2LL & 377.988 & & & $\mathrm{~T} 1=37.111, \mathrm{~T} 2=275.032$ & &
\end{tabular}


377.988-(37.111+272.32) = 65.845 değeri ile 3 serbestlik dereceli ki-kare değeri arasında $H_{0}$ hipotezi reddedilmiştir ( $H_{0}$ Etkileşimsiz Model). Buna göre tabakalı cox regresyon modelinin kullanılmasına karar verilmiştir.

Veri kapsamında yer alan maden ocaklarında ölümlü kaza oluncaya kadar geçen sürede "işçi sayısı" için kurulan tabakalı Cox regresyon modelinde yorumlamanın ancak işçi sayısının 100'den küçük olduğu durumda (T1) yapılması uygun bulunmuştur. Buna göre uygun koşullar altında yapılan havalandırmaya sahip ve işçi sayısının 100'den küçük olduğu maden ocaklarında kaza olma riski, havalandırılmayanlara göre yaklaşık 4.63 kat daha fazladır. Burada kaza oluncaya kadar süre ile ilgilenildiğinden bu ilişkinin negatif anlamını açıklamaktadır. Yani havalandırmaya sahip maden ocağında ölümlü kaza oluncaya kadar geçen süre havalandırılmayanlara göre daha uzun sürede gerçekleşmektedir. Aynı şekilde uygun gaz ölçüm koşullarına sahip maden ocaklarında kaza olma riski uygun olmayan gaz ölçüm koşullarına göre yaklaşık 10.38 kat daha fazladır. Bir başka deyişle uygun gaz ölçüm koşullarına sahip madenlerde kazalar daha uzun sürede gerçekleşmektedir. Kömür tozu gibi sürekli olan risk faktörlerinde böylesi bir kattan bahsedilemez.

\section{SONUÇLAR}

Son yıllarda meydana gelen kaza istatistikleri incelendiğinde madencilik sektöründe iş kazalarının giderek artığı görülmektedir [14,17]. Madencilik sektörü, doğası gereği bilgi, deneyim, uzmanlık ve sürekli denetim gerektiren dünyanın en zor ve riskli iş kollarından birisidir. Madencilik faaliyetleri sırasında birçok iş kazası meydana gelmektedir. Maden kazalarının nedenleri incelendiğinde, teknik, ekonomik, eğitim, planlama ve denetim sorunları gibi pek çok faktör tespit edilmektedir [17].

Maden kazaları detaylı olarak incelendiğinde ülkerler arası farklılık tespit edilmiştir. Türkiye Maden İşçileri Sendikası, ILO verilerine göre Türkiye'nin ölümlü maden kazaları listesinde sayısını 100 binde 133, Kore'de 122, Çin'de 106, Pakistan'da 74, İrlanda'da 53, Arjantin'de ise 37 olarak açıklamışlardır [53,54]. Bununla birlikte Türkiye'de yapılan çalışmalarda genellikle maden kazalarına ait nedenler belirlenirken yurtdışında olan çalışmalarda kaza nedenleri ve onların modellenmesine daha çok ağırlık verilmiştir. Türkiye'de yapılan çalışmalar sonucunda kaza nedenleri daha çok göçük, yer altında meydana gelen patlamalar ve yangınlar, havalandırmadaki eksiklikler, kişisel koruyucu donanımı eksikliği, grizu patlaması, kömür tozu patlaması, su baskını olarak belirlenmiştir $[12,13,14,22,23,25,26]$. Yurtdışında yapılan çalışmalarda veri madenciliği, sınıflandırma analizi, lojistik regresyon, bulanık mantık çözümlemesi, yapısal eşitlik modellemesi gibi istatistiksel çözümlemeler kullanılmıştır $[11,20,29,32,33,36]$. Bu çözümlemeler sonucu ve ayrı olarak incelenen pek çok makalede maden kazalarının nedenleri olarak bireye özgü faktörler, yönetimsel faktörler, yangın, patlatma, malzeme ve insan taşımacılığı, göçük, grizu patlaması, su basması, elektrik arızası, havalandırma olarak tespit edilmiştir [10,11,20,29,31,32,33,37].

Bu çalışmada Türkiye'de yeraltı kömür ocaklarında belli bir sürede meydana gelen ölümlü kazaların incelenmesinde Cox regresyon modeli kullanılmıştır. Bu modele göre ölümlü kaza gerçekleşinceye kadar olan sürede etkili olduğu düşünülen faktörlerden sadece işçi sayısı, havalandırma, gaz ölçüm koşulları ve kömür tozu miktarı modele alınmıştır. Ancak Cox regresyon modelinin kurulması için gerekli koşullardan biri olan orantılı hazard varsayımı incelendiğinde “iş̧̧i sayısı” risk faktörünün bu varsayımı sağlamadığı tespit edilmiştir. Bu amaçla tabakalı Cox regresyon modelinin kullanılmasına karar verilmiştir. Tabakalı Cox regresyon modeli sonucunda etkileşimli modelin kullanılmasına 
ve işçi sayısının 100'den küçük olan madenlerde yorumlamanın yapılmasına karar verilmiştir. Bu modele göre uygun havalandırma ve gaz ölçümlerinin yapılması ile Türkiye’deki kömür madenlerinde ölümlü kaza geçinceye kadar olan sürenin arttığı tespit edilmiştir. Ancak veri sayısının yıllar ve madenler bazında artırılması ile bu sonuca daha başka risk faktörlerinin ekleneceği gerçeği göz önüne alınmalıdır.

Madencilik sektöründe iş kazalarını içine alan güvenlik sorunları için Türkiye'de ve dünyada deneyimli kurumların varlığının artırılması, yeterli ve etkin yapılandırılmanın, üretimin, tekniğin ve alt yapının sağlanması ön plana çıkarılmalıdır. Ayrıca gerekli kanuni düzenlemelerin yapılmasına başlanmış ancak gerekli adımlara henüz ulaşılamamıştır. Bu yüzden son yıllarda iş güvenliği ve eğitimi ile ilgili yapılan çalışmalarda önem verilmelidir.

\section{KAYNAKLAR}

[1] Yaşar, S., İnal, S., Yaşar, Ö. \& Kaya, S. (2015). Geçmişten günümüze büyük maden kazaları. Madencilik, $52(2), 33-43$.

[2] T.C. Enerji ve Tabii Kaynaklar Bakanlığı (ETKB) (2018). Kömür. Eri im Tarihi: 08.10.2018, http:// www.enerji.gov.tr/tr-TR/Sayfalar/Komur

[3] Ceylan, H.\&Başhelvacı, V. (2011). Risk değerlendirme tablosu yönetimi ile risk analizi: Bir uygulama. International Journal of Engineering Research and Development, 3 (2), 25-33.

[4] Ergun, A.R. (2007). Yeraltı madeni i) letmelerinde gaz ve toz patlamalar ve önlemler. ş SaÝlıý1 ve Güvenliği Uzmanlık Tezi, Ankara.

[5] Önder, M., Mutlu, M., Adıgüzel, E. \& Önder, S. (2015). TKI’ye bă̆lı açık işletme kömür madenlerindeki iş günü kayıplı iş kazalarının aşamalı loglineer analiz yöntemi ile değerlendirilmesi. Türkiye 24. Uluslararası Madencilik Kongresi Bildiriler Kitabı, Antalya, 178189.

[6] Aydın, U., Gökçek Karaca, N., Canbey Özgüler, V., \& Karaca, E. (2013). İş sağlığ1 ve güvenliği eğitiminin iş kazaları ve meslek hastalıklarının önlenmesindeki rolü. Çimento Endüstrisi ${ }_{4}^{\prime}$ Verenleri Sendikası,
27, 26-45.

[7] Tanır, F. (2009). Madenlerde i) sa) l) l ve güvenli, ine bakış. Maden İşletmelerinde İş Sağllğ̆1 ve Güvenliğ̊ Sempozyumu Bildiriler Kitabı, Adana, 7-8.

[8] Derin, L., Varol, N. \& Uymaz, S. (2017). Türkiye'deki kömür madeni kazalarına ilişkin değerlendirme. Journal of Resillience, 1 (1), 47-53.

[9] Lirong, W, Zhongan, J., Weimin, C., Xiuwei, Z., Dawei, L., \& Yujing, Y. (2011). Major accident analysis and prevention of coal mines in China from the year of 1949 to 2009. Mining Science and Technology, 21, 693-699.

[10] Chen, H., Qi, H., Long, R., \& Zhang, M. (2012). Research on 10-year tendency of China coal mine accidents and the characteristics of human factors. Safety Science, 50 (4), 745-750.

[11] Mahdevari, S., Shahriar, K., \& Esfahanipour, A. (2014). Human health and safety risks management in underground coal mines using fuzzy TOPSIS. Science of the Total Enviroment, 85-99.

[12] Bilim, S. (2015). Kömür madenlerinde meydana gelen iş kazalarının istatistiksel değerlendirilmesi. Madencilik, Ocak, 78-82.

[13] Selçuk, A.S., Karpuz, C., Düzgün, H.Ş.B. \&Sari, M. (2000). Analysis of Tunçbilek underground coal mine accidents based on risk analysis techniques. Environmental Issues and Management of Waste in Energy and Mineral Production, 237-243.

[14] Önder, S. \& Önder, M. (2010). TKİye bağlı işletmelerde yaralanmalı iş kazalarının analizi. Madencilik Dergisi, 49 (3), 3-12.

[15] Önder, S., Adıgüzel, E. \& Önder, M. (2013). Açık işletme kömür madenciliğinde iş makineleri ile iliş̧kili kazaların analizi. Türkiye Uluslararası 23. Madencilik Kongresi ve Sergisi Bildiriler Kitabı, Antalya, 18951901.

[16] Önder, S. \& Mutlu, M. (2014). Açık i) letme kömür madenciliğinde lojistik regresyon analizi ile iş kazalarnın değerlendirilmesi. Türkiye 19. Kömür Kongresi Bildiriler Kitabı, Zonguldak, 341-352.

[17] TMMOB. (2010). Madencilikte yașanan iș kazalar raporu. Eri im Tarihi: 20.09.2018, http:// www.maden.org.tr/resimler/ ekler/9bd3e8809c72d94_ek.pdf

[18] Honert, A. (2014). Estimating the continuous risk of accident occuring in the South African mining industry. University of Stellenbosch. 8 e degree of master enginee- 
ring, Department of Engineering, Matieland, South Africa.

[19] Khuluqui, M.H., Prapdito, R.R. \& Sambodo, F.P. (2018). Prediction accident triangle in maintenance of underground mine facilities using poisson distirbution analysis. Materials Science and Engineering, 337, 1-6.

[20] Verma, S. \& Chaudhari, S. (2017). Safety of workers in Indian mines: Study, analysis, and prediction. $\mathrm{Sa}$ fety and Health at Work, 8, 267-275.

[21] SWA (State of Western Australia). (2018). Safety performance in the Western Australian mineral industry -accident and injury statistics 2016-17. Department of Mines, Industry Regulation and Safety.

[22] Güyagüler, T. (2002). Türkiye'de meydana gelen grizu patlamalarının irdelenmesi ve önlem önerileri. Türkiye 13. Kömür Kongresi Bildiriler Kitabı, Zonguldak, 45 -51 .

[23] Okyay, V. (2014). Yer altı kömür madenciliğinde iş kazaları ve teknolojik altyapı. Maden Mühendisi Madencilik Türkiye Dergisi, Temmuz, 84-88.

[24] Duzgun, H.S.B.\& Einstein, H.H. (2004). Assessment and management of roof fall risks in underground coal mines. Safety Science, 42, 23-41.

[25] Sari, M., Duzgun, H.S.B., Karpuz, C., \& Selcuk, A.S. (2004). Accident analysis of two Turkish underground coal mines. Safety Science, 42 (8), 675690.

[26] Arslanhan, S. \& Cünedioğlu, E. H. (2010). Madenlerde yaşanan iş kazaları ve sonuçları üzerine bir değerlendirme. Türkiye Ekonomi Politikaları Ara tırma Vakfı. Erişim Tarihi: 17.09.2018. https:// docplayer.biz.tr/5558-Madenlerde-yasanan-is-kazalari -ve-sonuclari-uzerine-bir-degerlendirme-selinarslanhan-arastirmaci.html.

[27] Akgün, M. (2015). Coal mine accidents. Turkish Thoracic Journal: Respiratory Emergencies in Coal Mines, 16, 1-2.

[28] Küçük, F.Ç.U. \& Ilgaz, A. (2015). Causes of coal mine accidents in the world and Turkey. Turkish Thoracic Journal: Respiratory Emergencies in Coal Mines, 16, 9-14.

[29] Zhu, J. \& Xiao-Ping, M. (2009). Safety evaluation of human accidents in coal mine based on ant colony optimization and SVM. Procedia Earth and Planetary Science, 1, 1418-1424.

[30] Grayson, L., Kinilakodi, H., \& Kecojevic, V. (2009).
Pilot sample risk analysis for underground coal mine fires and explosions using MSHA citation data R. Safety Science, 47, 1371-1378.

[31] Brnich, M., \& Kowalski, T. K. M. (2018). Underground coal mine disasters 1900-2010: Events, responses, and a look to the future. Erişim Tarihi 17.09.2018, https://www.cdc.gov/niosh/mining/ userfiles/works/pdfs/ucmdn.pdf

[32] Sanmiquel, L., Freijo, M., Edo, J., \& Rossell, J.M. (2010). Analysis of work related accidents in the Spanish mining sector from 1982-2006. Journal of Safety Research, 41, 1-7.

[33] Riba, S.J., Lesaoana, M., Sigauke, C. \& Makwela, M.R. (2011). A logistic regression analysis of the occurrence of mine accidents in the Burgersfort area in South Africa. Journal of Geology and Mining Research, 3 (1), 188-192.

[34] Wang, L., Cheng, Y.P., \& Liu, H.Y. (2014). An analysis of fatal gas accidents in Chinese coal mines. Safety Science, 62, 107-113.

[35] Harris, J., Kirsch, P., Shi, M., Li, J. \& Gagrani, A. (2014). Comparative analysis of coal fatalities in Australia, South Africa, India, China and USA, 20062010. Coal Operators' Conference, The University of Wollongong, 399-407.

[36] Zhang, Y., Shao, W., Zhang, M., Li, H., Yin, S., \& $\mathrm{Xu}, \mathrm{Y}$. (2016). Analysis 320 coal mine accidents using structural equation modeling with unsafe conditions of the rules and regulations as exogenous variables. Accident Analysis and Prevention, 92, 189201.

[37] Yin, W., Fu, G., Yang, C., Jiang, Z., Zhu, K.,\& Gao, Y. (2017). Fatal gas explosion accidents on Chinese coal mines and the characteristics of unsafe behaviors: 2000-2014. Safety Science, 92, 173-179.

[38] Sanmiquel, L, Bascompta, M., Rossell, J.M., Francisco, A. \&Guash, E. (2018). Analysşs of occuppational accidents in underground and surface mining in spain using data-mining techniques. International Journal of Environmental Research and Public Health, 15 (462), 1-11.

[39] Karasoy, D. (2008). Cox regresyon modeli ve akciğer kanseri verileri ile bir uygulama. ${ }_{4}$ statistikçiler Dergisi, 1, 16-22.

[40] Kaplan, E.L., Meier, P. (1958). Nonparametric estimation from incomplete observations. Journal of the American Statistical Association, 53 (282), 457- 481. 
[41] Topçu, Ç. (2007). Greenwood ve Kaplan-Meier meodu yardımı ile varyans tahmini. Ankara Üniversitesi Yüksek Lisans Tezi, Ankara.

[42] İnceoğlu, F. (2013). Sa) kalım analiz yöntemleri ve karaciğer nakli verileri ile bir uygulama. T.C. şnönü Üniversitesi, YL Tezi, Malatya.

[43] Ata, N., Sertkaya Ulusoy, D. \& Sözer, M.T. (2007). Sağkalım analiz yöntemleri ve karaciğer nakli verileri ile bir uygulama. Eski)ehir Osmangazi Üniversitesi Müh. Mim. Fak. Dergisi, XX, (1), 57-80.

[44] Abdelaal, M.M.A. \& Zakria, S.H.E.A. (2015). Modeling survival data using cox regression model. American Journal of Theoretical and Applied Statistics, 4 (6), 504-512.

[45] Punami, S.W., Inayati, K.D, Wulan Sari, N.W., Chosuvivatwongi V. \& Sriplung, H. (2016). Survival analysis of cervical cancer using stratified cox regression. Symposium on Biomathematics, AIP Conf. Proceeding, 1723, 030018, 1-7.

[46] Therneau, T.M. \& Grambsch, P.M. (2000). Modelling survival data: Extending the Cox model. New York: Springer.

[47] Klein, J.P. \& Moeschberger, M.L. (2003). Survival analysis: Techniques for cencored and truncated data. Second Edition, Springer, New York, USA.

[48] Persson, I., \& Khamis, H. J. (2007). A comparison of graphical methods for assessing the proportional hazards Assumptions in the Cox model. Journal of Statistics and Applications, 2, 1-32.

[49] Terzi, Y., Cengiz, M.A. \& Bek, Y. (2005). Cox regresyon modelinde oransal hazard varsayımının artıklarla incelenmesi ve akciğer kanseri hastaları üzerinde uygulanması. Türkiye Klinikleri J Med Sci, 25, 770775.

[50] Schoenfeld, D. (1982). Partial residuals for the proportional hazards regression model. Biometrika, 69, 239-241.

[51] Yay, M., Çoker, E. \& Uysal, Ö. (2007). Yaşam analizinde Cox regresyon modeli ve artıkların incelenmesi. Cerrahpaşa Tip Dergisi, 38, 139-145.

[52] Winnett, A. \& Sasieni, P. (2001). Miscellanea. A note on scaled Schoenfeld residuals for the proportional hazards model. Biometrika, 88, 565-571.

[53] Türkiye Maden İşçileri Sendikası. (2011). Basın Açıklaması: Maden kazaları Türkiye'yi birinci yaptı. Erişim Tarihi: 20.09.2018, http:// ekonomi.haber7.com/ekonomi/haber/759581-maden -kazalari-turkiyeyi-1inci-yapti

[54] ILO (1995). Recent developments in the coal mining industry. Coal Mines Committee, 13th Session, Report I, Geneva. 